\title{
Protein tyrosine phosphatase PTPN21 acts as a negative regulator of ICAM-1 by dephosphorylating IKK $\beta$ in TNF- $\alpha$-stimulated human keratinocytes
}

\author{
Young-Chang Cho, Ba Reum Kim \& Sayeon Cho* \\ College of Pharmacy, Chung-Ang University, Seoul 06974, Korea
}

\begin{abstract}
Intercellular adhesion molecule-1 (ICAM-1), which is induced by tumor necrosis factor (TNF)- $\alpha$, contributes to the entry of immune cells into the site of inflammation in the skin. Here, we show that protein tyrosine phosphatase non-receptor type 21 (PTPN21) negatively regulates ICAM-1 expression in human keratinocytes. PTPN21 expression was transiently induced after stimulation with TNF- $\alpha$. When overexpressed, PTPN21 inhibited the expression of ICAM-1 in HaCaT cells but PTPN21 C1108S, a phosphatase activity-inactive mutant, failed to inhibit ICAM-1 expression. Nuclear factor-kB (NF-kB), a key transcription factor of ICAM-1 gene expression, was inhibited by PTPN21, but not by PTPN21 C1108S. PTPN21 directly dephosphorylated phospho-inhibitor of $\kappa B$ (IKB)-kinase $\beta$ (IKK $\beta$ ) at Ser177/181. This dephosphorylation led to the stabilization of $I_{\kappa} B \alpha$ and inhibition of NF- $\mathrm{B}$ activity. Taken together, our results suggest that PTPN21 could be a valuable molecular target for regulation of inflammation in the skin by dephosphorylating $p$-IKK $\beta$ and inhibiting NF-KB signaling. [BMB Reports 2017; 50(11): 584-589]
\end{abstract}

\section{INTRODUCTION}

A critical step in the development of inflammatory skin diseases is the infiltration of various immune cells, such as monocytes, neutrophils, and activated T cells, from the blood into the skin (1). Upon stimulation with proinflammatory agents, including tumor necrosis factor (TNF)- $\alpha$ and interferon (IFN)- $\gamma$, keratinocytes in the skin express proinflammatory cytokines, chemokines, and adhesion molecules, like inter-

*Corresponding author. Tel: +82-2-820-5595; Fax: +82-2-8167338; E-mail: sycho@cau.ac.kr

https://doi.org/10.5483/BMBRep.2017.50.11.169

Received 26 August 2017, Revised 22 September 2017, Accepted 28 September 2017

Keywords: Inhibitor of $\mathrm{\kappa B}$ kinase, Intercellular adhesion molecule-1, Nuclear factor kappaB, Protein tyrosine phosphatase non-receptor type 21, Skin inflammation cellular adhesion molecule-1 (ICAM-1), which contribute to the entry of immune cells from the blood into the site of inflammation in the skin $(2,3)$.

TNF- $\alpha$ is a major proinflammatory cytokine produced by a number of cells, including keratinocytes (4). Stimulation of keratinocytes with TNF- $\alpha$ leads to activation of nuclear factor- $\mathrm{\kappa B}(\mathrm{NF}-\mathrm{\kappa} \mathrm{B})$ and subsequently increases the expression of adhesion molecules and proinflammatory genes $(5,6)$. NF- $\kappa B$ activation by TNF- $\alpha$ is due to the activation of the inhibitor of $\kappa \mathrm{B}(\mathrm{I} \mathrm{KB}$ )-kinases (IKKs) complex, an upstream kinase complex of $I_{\kappa} B \alpha$, which phosphorylates $1 \kappa B \alpha$ at Ser32/36, resulting in its ubiquitination and subsequent proteasomal degradation (7). Degradation of $\mathrm{I} \kappa \mathrm{B} \alpha$ leads to translocation of cytosolic NF- $\kappa \mathrm{B}$ complexes into the nucleus, where they activate the transcription of proinflammatory target genes (7).

Protein tyrosine phosphatase non-receptor type 21 (PTPN21), also known as PTPD1, is localized in the cytoplasm and phosphorylated by the proto-oncogene tyrosine-protein kinase (Src) $(8,9)$. It also upregulates Src by dephosphorylating Src at Tyr527 in response to stimulation by growth factors (10). PTPN21 forms a complex with actin, Src, and focal adhesion kinase (FAK), localizes at focal adhesion sites, and exerts major effects on cell adhesion, scattering, and migration (11). Through the formation of complex with A-kinase anchor protein 121 (AKAP121), PTPN21 plays diverse roles in cellular processes. Efficient maintenance of mitochondrial membrane potential and ATP oxidative synthesis occur via the PTPN21-Src-AKAP121 complex (12). When not in complex with AKAP121, PTPN21 activates extracellular signal-regulated kinases 1/2- and Elk1-dependent gene transcription by directing epidermal growth factor/Src signaling to the nucleus (10). PTPN21 activates Etk, a member of the Tec family kinases, by specific interaction with Etk, resulting in the activation of Janus kinase 2-independent signal transducer and activator of transcription 3 (13). However, other substrates of PTPN21 involved in the regulation of cellular signal transduction pathways remain to be identified.

Previous studies on the regulation of ICAM- 1 expression and skin inflammation focused on the findings of chemical or plant-extracted components and the elucidation of their mechanisms of action. In this study, we investigated PTP 
candidates that can regulate the expression of ICAM-1 and identified PTPN21 as a potential candidate. We examined the effect of PTPN21 on TNF- $\alpha$-induced ICAM-1 expression and the role of PTPN21 in the regulation of NF- $\mathrm{KB}$ signaling in a human keratinocyte cell line, HaCaT. Our study may provide a basis for the therapeutic use of PTPN21 in inflammatory skin diseases.

\section{RESULTS}

\section{TNF- $\alpha$ regulates ICAM-1 and PTPN21 expression in HaCaT cells}

TNF- $\alpha$ is one of the most critical cytokines that induce the expression of ICAM-1, which is an important adhesion molecule for the recruitment of various immune cells to inflammatory sites. To identify PTPs that are regulated by TNF- $\alpha$ in keratinocytes, we investigated how PTP gene expression changes upon TNF- $\alpha$ treatment. ICAM-1 mRNA expression was induced $1 \mathrm{~h}$ after TNF- $\alpha$ treatment and remained constant until $3 \mathrm{~h}$. Of the forty-nine PTPs tested (Supplementary table 1), PTPN21 expression was induced by TNF- $\alpha$ treatment, whereas other PTPs showed unchanged or decreased expression (Fig. 1A). This implies that the PTPN21 gene is induced by TNF- $\alpha$ and might be involved in the regulation of ICAM-1 expression. We then measured the expression profiles of PTPN21 and ICAM-1 proteins at different time points of TNF- $\alpha$ treatment to investigate the relationship between PTPN21 and ICAM-1 expression (Fig. 1B). ICAM-1 expression started to increase at $3 \mathrm{~h}$, showed maximal expression at $12 \mathrm{~h}$, and decreased from $24 \mathrm{~h}$ after TNF- $\alpha$ treatment, whereas PTPN21 expression increased until $24 \mathrm{~h}$ after TNF- $\alpha$ treatment and thereafter decreased.

A

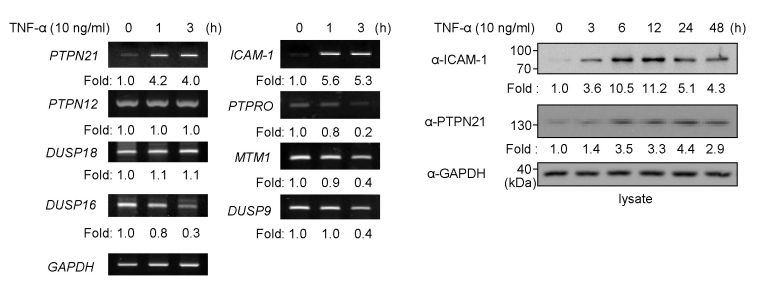

Fig. 1. TNF- $\alpha$ treatment regulates PTPN21 expression. (A) After stimulation of HaCaT cells with TNF- $\alpha(10 \mathrm{ng} / \mathrm{ml})$ for the indicated time periods $(0,1$, and $3 \mathrm{~h})$, total RNA was extracted and CDNA was synthesized. Expression levels of PTPs in each sample were determined by RT-PCR. Expression levels of each PTP, relative to GAPDH levels, were represented as fold changes in comparison with the untreated group. (B) Total cell lysates were prepared after TNF- $\alpha(10 \mathrm{ng} / \mathrm{m})$ stimulation for the indicated time periods $(0,3,6,12,24$, and $48 \mathrm{~h})$. Immunoblotting analysis was performed using anti-ICAM-1 and anti-PTPN21 antibodies. Each protein level was normalized to endogenous GAPDH levels and the relative values compared to the untreated group were represented as fold changes.

\section{PTPN21 inhibits TNF- $\alpha$-induced ICAM-1 expression in HaCaT cells}

As shown in Fig. 1B, a correlation between PTPN21 and ICAM-1 expression upon TNF- $\alpha$ treatment was observed. We, therefore, investigated the effect of PTPN21 on TNF- $\alpha$-induced ICAM-1 expression in $\mathrm{HaCaT}$ cells. HaCaT cells were transfected with either PTPN21 wild type (WT) or a catalytically inactive C1108S mutant expression plasmid, and stimulated with TNF- $\alpha$ prior to mRNA extraction (Fig. 2A). TNF- $\alpha$ treatment increased ICAM-1 mRNA expression in HaCaT cells. While overexpression of PTPN21 WT inhibited the TNF- $\alpha$ induced expression of ICAM-1, PTPN21 C1108S overexpression failed to do so. Similarly, TNF- $\alpha$-induced ICAM-1 protein levels were tightly regulated by PTPN21 WT, but not by PTPN21 C1108S (Fig. 2B). These results suggest that PTPN21 WT regulates ICAM-1 gene expression and its phosphatase activity is required for gene regulation.

To confirm that PTPN21 affects the expression levels of ICAM-1, knockdown of PTPN21 gene expression was performed by transfecting $\mathrm{HaCaT}$ cells with PTPN21-targeting siRNAs. By performing siRNA transfection followed by immunoblotting analysis with anti-PTPN21 antibody, siRNA\#1

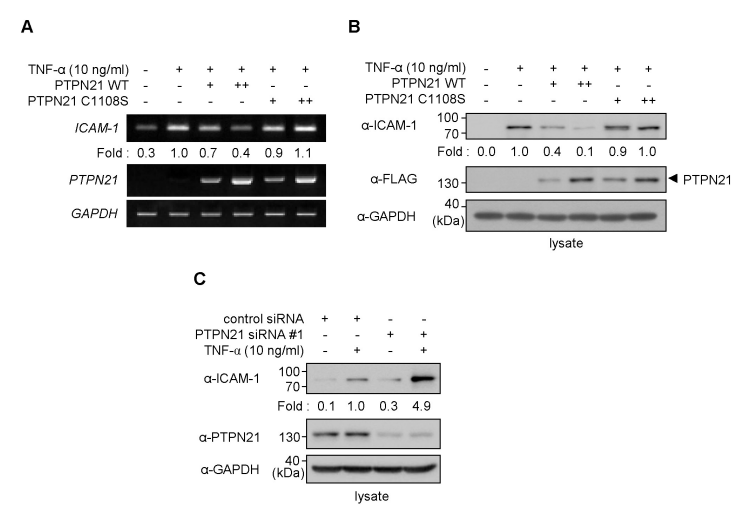

Fig. 2. PTPN21 inhibits ICAM-1 production. (A and B) HaCaT cells were transfected with FLAG-PTPN21 plasmids (WT or C1108S; 1 $\mu \mathrm{g}$ for + or $2 \mu \mathrm{g}$ for ++ ) for $48 \mathrm{~h}$. (A) After stimulation with TNF- $\alpha(10 \mathrm{ng} / \mathrm{ml})$ for $1 \mathrm{~h}$, total RNA was extracted and CDNA was synthesized. Expression levels of ICAM-1 and PTPN21 in each sample were measured by RT-PCR. ICAM-1 expression levels were normalized to GAPDH levels and the relative values compared to the TNF- $\alpha$-treated group were represented as fold changes. (B) Total cell lysates were prepared after TNF- $\alpha$ (10 $\mathrm{ng} / \mathrm{ml}$ ) stimulation for $12 \mathrm{~h}$. Immunoblotting analysis was performed using appropriate antibodies. ICAM-1 protein levels were normalized to endogenous GAPDH levels and the relative values compared to the TNF- $\alpha$-treated group were represented as fold changes. (C) HaCaT cells were transfected with control siRNA (50 $\mathrm{nM})$ or PTPN21 siRNA\#1 (100 nM) for $45 \mathrm{~h}$ and were stimulated with TNF- $\alpha(10 \mathrm{ng} / \mathrm{ml})$ for $3 \mathrm{~h}$. ICAM-1 protein levels were determined by immunoblotting analysis with appropriate antibodies. ICAM-1 protein levels were normalized to endogenous GAPDH levels and the relative values compared to control siRNAtransfected group were represented as fold changes. 
was selected to inhibit the expression of PTPN21 in HaCaT cells throughout this study (Supplementary Fig. 1). PTPN21 knockdown enhanced the TNF- $\alpha$-induced expression of ICAM-1, compared to transfection with non-targeting control siRNA (Fig. 2C). This result suggests that PTPN21 negatively regulates the TNF- $\alpha$-induced ICAM-1 expression in HaCaT cells.

\section{PTPN21 inhibits TNF- $\alpha$-induced NF- $\kappa$ B activation in HaCaT cells}

TNF- $\alpha$ activates NF- $\mathrm{KB}$ signaling to induce ICAM- 1 expression (14). To verify that PTPN21-mediated decrease in ICAM-1 expression is a result of NF-kB inhibition, knockdown of endogenous PTPN21 expression in $\mathrm{HaCaT}$ cells was performed by transfection with PTPN21 siRNA\#1. NF-kB transcriptional activities were then measured using a NF- $\kappa B$ reporter system. As shown in Fig. 3A, in the absence of TNF- $\alpha$ treatment, $\mathrm{NF}-\mathrm{\kappa B}$ transcriptional activities, which are represented as luciferase activities, were not distinguishable between control siRNA- and PTPN21 siRNA\#1-transfected cells. However, PTPN21 knockdown cells showed a significant increase in NF- $\mathrm{KB}$ activity compared to control siRNA-transfected cells upon exposure to TNF- $\alpha$.

Next, we investigated the effect of PTPN21 WT or C1108S overexpression on TNF- $\alpha$-induced $\mathrm{NF}-\kappa \mathrm{B}$ transcriptional activity in $\mathrm{HaCaT}$ cells. As shown in Fig. 3B, TNF- $\alpha$-induced NF-kB activity was reduced by PTPN21 WT, whereas PTPN21 C1108S did not exert any inhibitory effect on NF-кB activity. These results imply that PTPN21 inhibits NF- $\mathrm{KB}$ transcriptional activity in a phosphatase activity-dependent manner.

\section{PTPN21 inhibits IKB and IKKs phosphorylation in HaCaT cells by its phosphatase activity}

The reporter assay results prompted us to investigate the alterations in NF- $\mathrm{KB}$ activation by silencing PTPN21 in $\mathrm{HaCaT}$ cells. PTPN21 knockdown was achieved by transfecting HaCaT cells with PTPN21-targeting siRNA\#1. As shown in Fig. $3 \mathrm{C}$, TNF- $\alpha$-induced phosphorylation and degradation of IKB $\alpha$ significantly increased in PTPN21 siRNA-transfected cells compared to control siRNA-transfected cells. In addition to the effect on IKB $\alpha$, IKK phosphorylation was also notably increased in PTPN21 knockdown cells. These results indicate that PTPN21 inhibits NF- $\mathrm{KB}$ transcriptional activity by regulating the phosphorylation of IKB $\alpha$ and IKK.

To elucidate a more concise mechanism of action of PTPN21 in the regulation of NF- $\kappa B$ signaling, the effects of PTPN21 on the phosphorylation of IкB $\alpha$ at Ser32/36 and IKKs (IKK $\alpha$ at Ser176/180 and IKK $\beta$ at Ser177/181) were determined by overexpressing PTPN21 WT and C1108S since phosphorylation at those sites is critical for NF- $\kappa B$ activation. Phosphorylation of IKB $\alpha$ and IKKs were induced by TNF- $\alpha$ stimulation in $\mathrm{HaCaT}$ cells. TNF- $\alpha$-induced phosphorylation and subsequent degradation of $\mathrm{I} \kappa \mathrm{B} \alpha$ were decreased by PTPN21 WT in a dose-dependent manner, whereas PTPN21 $\mathrm{C} 1108 \mathrm{~S}$ did not influence $\mathrm{l} \kappa \mathrm{B} \alpha$ phosphorylation and degradation

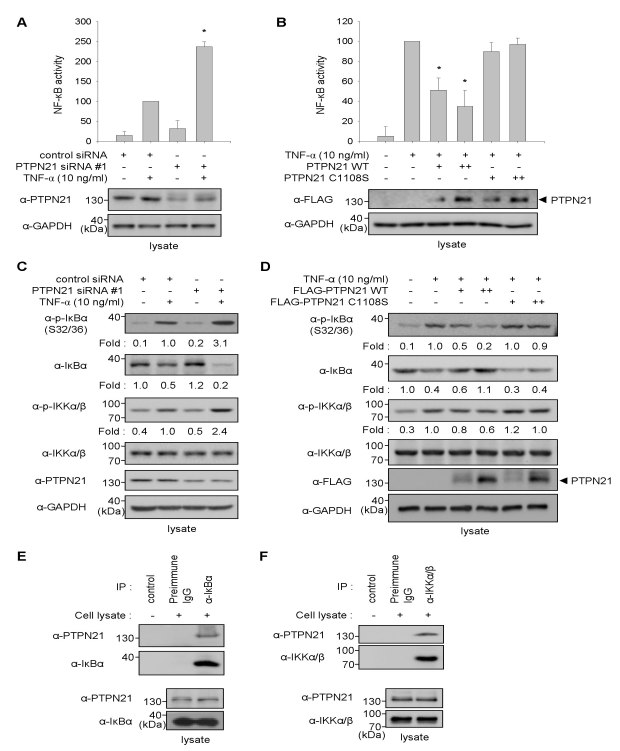

Fig. 3. PTPN21 inhibits NF- $\kappa B$ activation. (A) HaCaT cells were transfected with $\mathrm{pNF}-\kappa \mathrm{B}-\mathrm{luc}$ reporter plasmid containing a luciferase gene and a gWIZ-GFP plasmid, and subsequently transfected with control siRNA (50 nM) or PTPN21 siRNA\#1 (100 nM). After $24 \mathrm{~h}$ of incubation, the cells were treated with TNF- $\alpha(10 \mathrm{ng} / \mathrm{ml})$ and further incubated for $24 \mathrm{~h}$. The luciferase activities of each group were calculated using GFP fluorescence values as an internal control for transfection efficiency. Luciferase activities relative to control siRNA-transfected group were represented as a bar graph. ${ }^{*} \mathrm{P}<0.05$ relative to the TNF- $\alpha$-treated group. (B) HaCaT cells were transfected with $\mathrm{pNF}-\mathrm{\kappa B}-\mathrm{luc}$ reporter plasmid containing a luciferase gene and a gWIZ-GFP plasmid, and subsequently transfected with FLAG-PTPN21 WT or C1108S plasmids $1 \mu \mathrm{g}$ for + or $2 \mu \mathrm{g}$ for ++ ). After $24 \mathrm{~h}$ of incubation, the cells were treated with TNF- $\alpha(10 \mathrm{ng} / \mathrm{ml})$ and further incubated for $24 \mathrm{~h}$. The luciferase activities of each group were calculated using GFP fluorescence values as an internal control for transfection efficiency. Luciferase activities relative to the TNF- $\alpha$-treated group were represented as a bar graph. $* \mathrm{P}<0.05$ relative to the TNF$\alpha$-treated group. (C) HaCaT cells were transfected with control SiRNA $(50 \mathrm{nM})$ or PTPN21 siRNA\#1 $(100 \mathrm{nM})$ for $48 \mathrm{~h}$ and were stimulated with TNF- $\alpha(10 \mathrm{ng} / \mathrm{ml})$ for $10 \mathrm{~min}$. The levels of $\mathrm{p}-\mathrm{I} \kappa \mathrm{B} \alpha, \quad \mathrm{I} \kappa \mathrm{B} \alpha$, and $\mathrm{p}-\mathrm{IKK} \alpha / \beta$ were determined by immunoblotting analysis with appropriate antibodies. $\mathrm{p}-\mathrm{I} \kappa \mathrm{B} \alpha$ and $\mathrm{I} \mathrm{KB} \alpha$ levels were normalized to endogenous GAPDH levels, and $\mathrm{p}$-IKK $\alpha / \beta$ levels were normalized to total IKK levels. The relative values of each protein were represented as fold changes compared to contro siRNA-transfected group. (D) HaCaT cells were transfected with FLAG-PTPN21 plasmids (WT or C1108S; $1 \mu \mathrm{g}$ for + or $2 \mu \mathrm{g}$ for $++)$ for $48 \mathrm{~h}$. Total cell lysates were prepared after TNF- $\alpha(10$ $\mathrm{ng} / \mathrm{ml}$ ) stimulation for 15 min. Immunoblotting analysis was performed using appropriate antibodies. Relative levels of $\mathrm{p}-\mathrm{I} \kappa \mathrm{B} \alpha$ and $1 \kappa B \alpha$ were normalized to endogenous GAPDH levels, and that of $\mathrm{p}-\mathrm{IKK} \alpha / \beta$ (p-Ser176/180 of IKK $\alpha$ and $\mathrm{p}$-Ser177/181 of IKK $\beta$ ) was normalized to total IKK $\alpha / \beta$ levels. The values relative to the TNF- $\alpha$-treated group were represented as fold changes. ( $E$ and $F$ ) Total cell lysates from $\mathrm{HaCaT}$ cells were immunoprecipitated with anti-I $\mathrm{KB} \alpha(\mathrm{E})$ or anti-IKK$\alpha / \beta$ (F) antibody. The immunoprecipitates were subjected to immunoblotting analysis with anti-PTPN21 antibody to detect interaction. Endogenous expression of PTPN21, $I \kappa B \alpha$, and IKK $\alpha / \beta$ in total cell lysates was confirmed by immunoblotting analysis with each antibody. 
(Fig. 3D). Similar to the result of $1 \kappa B \alpha$ phosphorylation, PTPN21 WT led to dephosphorylation of $p-I K K \alpha / \beta$, whereas PTPN21 C1108S did not. These results indicate that the regulatory effects of PTPN21 on NF- $\mathrm{KB}$ signaling are due to the dephosphorylation of $p-I \kappa B \alpha$ and $p-I K K \alpha / \beta$ in a phosphatase activity-dependent manner.

To gain more insight into the direct target of PTPN21 for the regulation of NF- $\mathrm{KB}$ signaling, we examined the association between PTPN21 and the NF- $\kappa B$ signaling axis, including $\mid \kappa B \alpha$ and IKKs, which are the key molecules for NF-KB activation and are tightly regulated by phosphorylation in $\mathrm{HaCaT}$ cells. Immunoprecipitation of endogenous $\mathrm{I} \mathrm{KB} \alpha$ or $\mathrm{IKK} \alpha / \beta$ by specific antibodies and subsequent immunoblotting analysis with anti-PTPN21 antibody showed the association of $1 \kappa B \alpha$ and IKK $\alpha / \beta$ with endogenous PTPN21 in HaCaT cells (Fig. 3E and F). These data indicate that PTPN21 associates with endogenous $\mathrm{I} \kappa \mathrm{B} \alpha$ and IKK $\alpha / \beta$ in HaCaT cells.

\section{PTPN21 directly interacts with IKK $\beta$ and dephosphorylates p-IKK $\beta$}

The results of Fig. 3D-F provoke the question as to what is the direct dephosphorylating target of PTPN21 in the regulation of $\mathrm{NF}-\mathrm{\kappa B}$ signaling. IKK $\beta$ is activated through phosphorylation at Ser177/181 and it subsequently catalyzes the phosphorylation of $1 \kappa B \alpha$ at Ser32/36 (15). Therefore, we performed in vitro binding assays using recombinant His-PTPN21 protein expressed in and purified from bacteria to find out the direct association of PTPN21 with $I \kappa B \alpha$ and IKK $\beta$. When immunoprecipitated FLAG-I $\kappa B \alpha$ was incubated with recombinant His-PTPN21, no direct interaction between $1 \kappa B \alpha$ and PTPN21 WT was detected (Fig. 4A). However, immunoprecipitated FLAG-IKK $\beta$ showed an association with His-PTPN21 protein (Fig. 4B). These results indicate that IKK $\beta$ might be the direct target of PTPN21 in the regulation of NF- $\mathrm{KB}$ signaling.

To clarify whether PTPN21 directly dephosphorylates $\mathrm{p}-\mathrm{IKK} \beta$, but not $\mathrm{p}-\mathrm{I} \mathrm{K} \mathrm{B} \alpha$, we performed an in vitro phosphatase assay using recombinant His-PTPN21 WT or C1108S. Immunoprecipitates from FLAG-tagged I $\mathrm{BB} \alpha$ - or IKK $\beta$-transfected HEK 293 cells were extensively washed and then incubated with His-PTPN21 proteins followed by immunoblotting with phospho-specific antibodies. As shown in Fig. 4C, both His-PTPN21 WT and C1108 proteins did not dephosphorylate $\mathrm{p}-\mathrm{I} \kappa \mathrm{B} \alpha$ in vitro. However, His-PTPN21 WT decreased the levels of $p$-IKK $\beta$ at Ser177/181, whereas His-PTPN21 C1108S did not (Fig. 4D). These results suggest that PTPN21 directly dephosphorylates $\mathrm{p}$-IKK $\beta$ in a phosphatase activity-dependent manner, leading to dephosphorylation of $\mathrm{p}-\mathrm{l} \kappa \mathrm{B} \alpha$ in the cells.

\section{DISCUSSION}

Growing evidence indicates that adhesion molecules, such as ICAM-1 on the surface of epidermal keratinocytes, play important roles in the initiation and maintenance of skin inflammation $(3,16)$. Therefore, elucidating the signaling

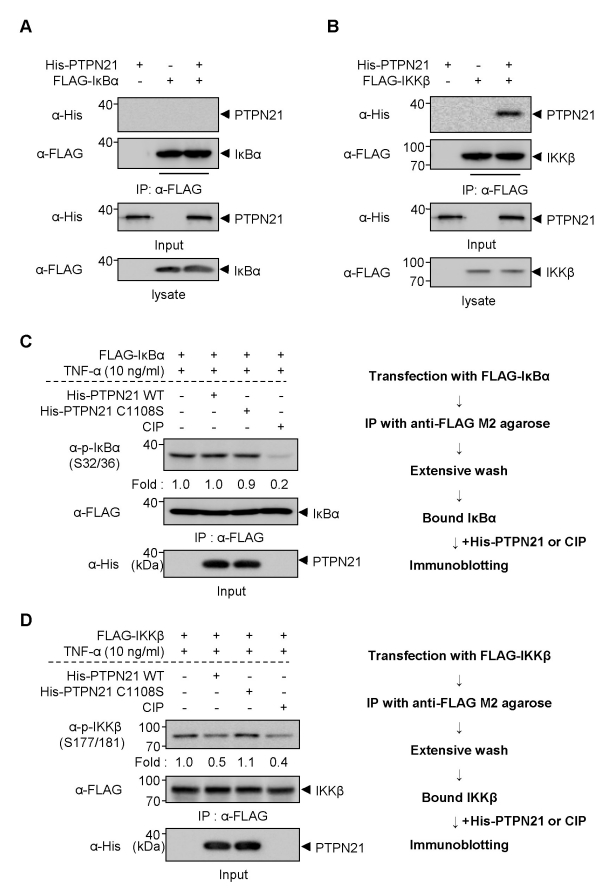

Fig. 4. PTPN21 directly dephosphorylates $p-I K K \beta$. (A and $B$ ) After transfection with FLAG-tagged $I \kappa B \alpha(A)$ or $I K K \beta$ (B), cell lysates were immunoprecipitated with anti-FLAG $M 2$ agarose and then mixed with purified His-PTPN21 WT proteins. After binding, the immunoprecipitates were subjected to immunoblotting analyses with indicated antibodies to detect direct interaction between the immunoprecipitated FLAG-tagged proteins and purified HisPTPN21. (C and D) After transfection with FLAG-tagged I $\mathrm{B} B \alpha(\mathrm{C})$ or IKK $\beta$ (D), cell lysates were immunoprecipitated with anti-FLAG M2 agarose and extensively washed. The immunoprecipitates were then reacted with purified His-PTPN21 WT or C1108S proteins in PTP reaction buffer. The reaction was stopped by adding sample buffer and the samples were subjected to immunoblotting analyses with indicated antibodies. CIP-treated group was used to detect the disappearance of $p-I \kappa B \alpha$ and $p-I K K \beta$ in immunoprecipitates.

molecules that regulate ICAM-1 expression as well as the discovery of pharmacological agents inhibiting ICAM-1 expression in keratinocytes are considered crucial for the treatment of inflammatory skin diseases. In this study, we showed that PTPN21 significantly inhibited the expression of ICAM-1 in TNF- $\alpha$-stimulated HaCaT cells, indicating that PTPN21 could be a potential cellular target for the treatment of inflammatory skin diseases. Further investigations, such as alleviation of TNF- $\alpha$-induced adhesion of monocytes to HaCaT cells by PTPN21, may be required to verify the consequences of PTPN21-mediated ICAM-1 inhibition.

A major signaling pathway activated by TNF- $\alpha$ is the NF- $\kappa B$ signal transduction pathway, which plays a central role in skin inflammatory responses by inducing the production of adhesion molecules, including ICAM- 1 and basal-cell adhesion molecule 
in epidermal keratinocytes (17). Upon cell stimulation with TNF- $\alpha$, the cytosolic NF- $\kappa B$ heterodimer is freed from $1 \kappa B \alpha$ and translocates into the nucleus, where it activates the transcription of proinflammatory genes (7). Our data and the molecular basis for regulation of NF-KB and ICAM-1 provide a clue that PTPN21 can regulate ICAM-1 expression in HaCaT cells by inhibiting NF-kB signaling.

PTPN21 is one of the class I PTPs, which consist of receptor type and non-receptor type PTPs, and has been reported to exhibit substrate specificity for phosphorylation at Tyr residues (9). However, in this study, PTPN21 dephosphorylated p-IKK $\beta$ at Ser177/181. This suggests that PTPN21 has a phosphatase activity towards $p$-Ser as well as $p$-Tyr. Protein tyrosine phosphatase receptor type $\mathrm{O}$, which is known as a Tyr-specific class I PTP, also has an ability to dephosphorylate p-Akt at Ser473 and p-glycogen synthase kinase $3 \beta$ (GSK3 $\beta$ ) at Ser9 (18). Furthermore, phosphatase and tensin homolog (PTEN), a Tyr- and lipid-specific PTP (19), dephosphorylates p-Akt at Ser473 and p-GSK3 $\alpha / \beta$ at Ser21/9 in insulin-like growth factor-II-overexpressing rhabdomyosarcomas cells (20). Our results as well as these reports imply that some receptor type and non-receptor type PTPs have phosphatase activity toward p-Ser as well as $p$-Tyr.

Using siRNAs targeting various phosphatases, Li et al. reported that a variety of phosphatases, including PTPN21, inhibit NF-KB transcriptional activity in mouse astrocytes (19). The inhibitory effects of some identified phosphatases and their underlying mechanisms of action on NF- $\mathrm{kB}$ activation were further elucidated. However, the involvement of PTPN21 in the regulation of NF- $\mathrm{KB}$ was not investigated at a molecular level.

In addition, there are several reports that protein phosphatases regulate NF- $\mathrm{KB}$ signaling. IKK $\beta$ phosphorylation and activation were observed when PP2A was inhibited by ultraviolet-B (UVB) radiation, leading to UVB-induced apoptosis $(21,22)$. PTEN reduced NF- $\mathrm{KB}$ DNA binding to the FAK promoter by inhibiting the $\mathrm{PI} 3 \mathrm{~K} / \mathrm{NF}-\mathrm{\kappa B}$ pathway, and subsequently inhibited invasion and metastasis of gastric cancer (23). Furthermore, profilin, a tumor suppressor protein, interacts with PTEN and suppresses NF-KB activity via inhibition of IKK phosphorylation (24). Unlike these phosphatases, no further investigations were available although PTPN21 seemed to be involved in the regulation of NF- $\mathrm{KB}$ activity (19). Therefore, the results of our study, which suggest that PTPN21 is a phosphatase activity-dependent regulator of $\mathrm{p}-\mathrm{IKK} \alpha / \beta$, provide valuable insights for understanding PTPN21mediated NF- $\kappa$ B regulation.

PTPN21 inhibits ICAM-1 expression by inhibiting the NF- $\kappa B$ signal transduction pathway in HaCaT cells (Fig. 2 and 3). PTPN21 also activates the Src signaling pathway, which has been known to induce ICAM-1 expression and phosphorylation, by dephosphorylating its inhibitory phosphorylation site at Tyr527 (10). These controversial effects of PTPN21 on the $\mathrm{NF}-\mathrm{\kappa B}$ and Src signaling pathways give rise to a hypothesis that the activation of NF- $\mathrm{kB}$ signaling is more dominant for ICAM-1 expression than that for $\mathrm{Src}$ in $\mathrm{HaCaT}$ cells. This hypothesis can be supported by a previous study, which reported that low-molecular-weight protein tyrosine phosphatase (LMW-PTP) is oncogenic or anti-oncogenic depending on its interaction with different substrates (25). LMW-PTP was revealed to induce cell migration, suggesting that its oncogenic properties are more dominant than its anti-oncogenic properties (25). Similarly, we assume that PTPN21-mediated activation of the $\mathrm{NF}-\kappa \mathrm{B}$ signaling pathway might be more crucial for regulating ICAM-1 expression compared to PTPN21-mediated activation of the Src signaling pathway.

$\mathrm{NF}-\kappa \mathrm{B}$ is usually considered as an anti-apoptotic factor since it promotes cell proliferation. The inhibitory effect of PTPN21 on the NF- $\kappa B$ signaling pathway seems controversial when compared to PTPN21-mediated activation of the Src signaling pathway and its promoting effects on cell motility and migration $(10,11)$. However, NF- $\kappa B$ activation by interleukin-1 leads to NF-kB-dependent secretion of TNF- $\alpha$, which activates TNF-R1 in an autocrine fashion to enhance UVB-induced apoptosis (26). These data suggest that PTPN21-mediated inhibition of TNF- $\alpha$-induced NF- $\mathrm{KB}$ signaling could have the same cancer-promoting effects as PTPN21-mediated Src activation. Further studies are needed to clarify the consequence of PTPN21-mediated NF-kB inhibition with regard to cancer promotion.

\section{MATERIALS AND METHODS}

See the supplementary informations.

\section{ACKNOWLEDGEMENTS}

We thank Dr. A. Feliciello for kindly providing us with FLAG-PTPN21 WT plasmid and anti-PTPN21 antibodies. This research was supported by the National Research Foundation of Korea (NRF) grant funded by the Ministry of Science, ICT \& Future Planning (NRF-2015R1A2A2A11001446 and 2015R1A 5A1008958) and by the Ministry of Education, Science and Technology (NRF-2016R1A6A3A11931134).

\section{CONFLICTS OF INTEREST}

The authors have no conflicting interests.

\section{REFERENCES}

1. Grone A (2002) Keratinocytes and cytokines. Vet Immunol Immunopathol 88, 1-12

2. Dustin ML, Singer KH, Tuck DT and Springer TA (1988) Adhesion of T lymphoblasts to epidermal keratinocytes is regulated by interferon gamma and is mediated by intercellular adhesion molecule 1 (ICAM-1). J Exp Med $167,1323-1340$ 
3. Trefzer U, Brockhaus $M$, Loetscher $\mathrm{H}$ et al (1991) 55-kd tumor necrosis factor receptor is expressed by human keratinocytes and plays a pivotal role in regulation of human keratinocyte ICAM-1 expression. J Invest Dermatol 97, 911-916

4. Kock A, Schwarz T, Kirnbauer R et al (1990) Human keratinocytes are a source for tumor necrosis factor alpha: evidence for synthesis and release upon stimulation with endotoxin or ultraviolet light. J Exp Med 172, 1609-1614

5. Bahar-Shany K, Ravid A and Koren R (2010) Upregulation of MMP-9 production by TNFalpha in keratinocytes and its attenuation by vitamin D. J Cell Physiol 222, 729-737

6. Seo WY, Youn GS, Choi SY and Park J (2015) Butein, a tetrahydroxychalcone, suppresses pro-inflammatory responses in HaCaT keratinocytes. BMB Rep 48, 495-500

7. Kim H, Youn GS, An SY, Kwon HY, Choi SY and Park J (2015) 2,3-Dimethoxy-2'-hydroxychalcone ameliorates TNF- $\alpha$-induced ICAM- 1 expression and subsequent monocyte adhesiveness via NF-kappaB inhibition and HO-1 induction in HaCaT cells. BMB Rep 49, 57-62

8. Barr AJ, Ugochukwu E, Lee WH et al (2009) Large-scale structural analysis of the classical human protein tyrosine phosphatome. Cell 136, 352-363

9. Moller NP, Moller KB, Lammers R, Kharitonenkov A, Sures I and Ullrich A (1994) Src kinase associates with a member of a distinct subfamily of protein-tyrosine phosphatases containing an ezrin-like domain. Proc Natl Acad Sci U S A 91, 7477-7481

10. Cardone L, Carlucci A, Affaitati A et al (2004) Mitochondrial AKAP121 binds and targets protein tyrosine phosphatase D1, a novel positive regulator of src signaling. Mol Cell Biol 24, 4613-4626

11. Carlucci A, Gedressi C, Lignitto L et al (2008) Proteintyrosine phosphatase PTPD1 regulates focal adhesion kinase autophosphorylation and cell migration. J Biol Chem 283, 10919-10929

12. Livigni A, Scorziello A, Agnese S et al (2006) Mitochondrial AKAP121 links CAMP and src signaling to oxidative metabolism. Mol Biol Cell 17, 263-271

13. Jui HY, Tseng RJ, Wen $X$ et al (2000) Protein-tyrosine phosphatase D1, a potential regulator and effector for Tec family kinases. J Biol Chem 275, 41124-41132

14. Thommesen L, Sjursen W, Gasvik K et al (1998) Selective inhibitors of cytosolic or secretory phospholipase A2 block TNF-induced activation of transcription factor nuclear factor-kappa $B$ and expression of ICAM-1. J Immunol 161, 3421-3430

15. Delhase M, Hayakawa M, Chen $Y$ and Karin M (1999) Positive and negative regulation of IkappaB kinase activity through IKKbeta subunit phosphorylation. Science 284, 309-313

16. Krutmann J, Czech W, Parlow F et al (1992) Ultraviolet radiation effects on human keratinocyte ICAM-1 expression: UV-induced inhibition of cytokine-induced ICAM-1 mRNA expression is transient, differentially restored for IFN gamma versus TNF alpha, and followed by ICAM-1 induction via a TNF alpha-like pathway. J Invest Dermatol 98, 923-928

17. Ali S and Mann DA (2004) Signal transduction via the NF-kappaB pathway: a targeted treatment modality for infection, inflammation and repair. Cell Biochem Funct $22,67-79$

18. Jiang R, Chen D, Hou J et al (2014) Survival and inflammation promotion effect of PTPRO in fulminant hepatitis is associated with NF-kappaB activation. J Immunol 193, 5161-5170

19. Li S, Wang L, Berman MA, Zhang Y and Dorf ME (2006) RNAi screen in mouse astrocytes identifies phosphatases that regulate NF-kappaB signaling. Mol Cell 24, 497-509

20. Wan X and Helman LJ (2003) Levels of PTEN protein modulate Akt phosphorylation on serine 473, but not on threonine 308, in IGF-II-overexpressing rhabdomyosarcomas cells. Oncogene 22, 8205-8211

21. Barisic S, Strozyk E, Peters N, Walczak H and Kulms D (2008) Identification of PP2A as a crucial regulator of the NF-kappaB feedback loop: its inhibition by UVB turns NF-kappaB into a pro-apoptotic factor. Cell Death Differ $15,1681-1690$

22. DiDonato JA, Hayakawa M, Rothwarf DM, Zandi E and Karin M (1997) A cytokine-responsive IkappaB kinase that activates the transcription factor NF-kappaB. Nature 388, 548-554

23. Zhang LL, Liu J, Lei S, Zhang J, Zhou W and Yu HG (2014) PTEN inhibits the invasion and metastasis of gastric cancer via downregulation of FAK expression. Cell Signal 26, 1011-1020

24. Zaidi AH and Manna SK (2016) Profilin-PTEN interaction suppresses NF-kappaB activation via inhibition of IKK phosphorylation. Biochem J 473, 859-872

25. Alho I, Costa L, Bicho M and Coelho C (2013) The role of low-molecular-weight protein tyrosine phosphatase (LMWPTP ACP1) in oncogenesis. Tumour Biol 34, 1979-1989

26. Poppelmann B, Klimmek K, Strozyk E, Voss R, Schwarz T and Kulms D (2005) NF kappaB-dependent downregulation of tumor necrosis factor receptor-associated proteins contributes to interleukin-1-mediated enhancement of ultraviolet B-induced apoptosis. J Biol Chem 280, $15635-15643$ 